Konsekwencje oraz postępowanie $w$ przypadku wczesnej utraty pierwszych stałych trzonowców u dzieci

\section{Consequences and management of early loss of first permanent molars in children}

\author{
Dorota Jabłonowska ABD (ORCID ID: 0000-0002-0231-1406) \\ Katarzyna Reszelewska ABD (ORCID ID: 0000-0001-9880-4610) \\ Piotr Smołka EF
}

\begin{abstract}
Wkład autorów: $\mathbf{A}$ Plan badań $\mathbf{B}$ Zbieranie danych $\mathbf{C}$ Analiza statystyczna $\mathbf{D}$ Interpretacja danych
$\mathbf{E}$ Redagowanie pracy $\mathbf{F}$ Wyszukiwanie piśmiennictwa

Authors' Contribution: A Study design $\mathbf{B}$ Data Collection $\mathbf{C}$ Statistical Analysis $\mathbf{D}$ Data Interpretation

$\mathbf{E}$ Manuscript Preparation $\mathbf{F}$ Literature Search
\end{abstract}

Prywatna Praktyka

Private practice

\section{Streszczenie}

Wczesna utrata pierwszych stałych zębów trzonowych u dzieci jest poważnym problemem niosącym za sobą liczne konsekwencje oraz stawiającym lekarza prowadzącego przed trudnym wyborem najwłaściwszego postępowania. Wymaga określenia procedury, która ograniczałaby wystąpienie niepożądanych skutków oraz stwarzała możliwie najkorzystniejsze warunki dla dalszego, prawidłowego rozwoju okluzji. Cel. Celem artykułu jest przedstawienie przeglądu piśmiennictwa na temat przyczyn oraz konsekwencji przedwczesnej utraty pierwszych stałych zębów trzonowych, a także zalecanego postępowania mającego na celu zminimalizowanie konieczności leczenia ortodontycznego w przyszłości. Materiał i metody. Przeprowadzono przegląd piśmiennictwa z lat 1970-2020 z wykorzystaniem medycznej bazy danych PubMed. Wyniki. Wczesna ekstrakcja pierwszych stałych zębów trzonowych ma wpływ na wzrost szkieletowy oraz dalszy rozwój uzębienia i okluzji. Może prowadzić do powikłań periodontologicznych, nieprawidłowej

\begin{abstract}
Early loss of first permanent molars in children is a severe problem with numerous consequences and poses a difficult dilemma for a clinician in choosing the most appropriate management. It requires defining a procedure to limit the occurrence of undesirable effects and to create the most favorable conditions for continued proper occlusion development. Aim. The aim of this study was to present a review of the literature about causes and consequences of early loss of first permanent molars and recommended management to minimize the need for orthodontic treatment in the future. Material and methods. Literature from the years 19702020 was reviewed using the PubMed medical database. Results. Early loss of first permanent molars affects skeletal growth and further development of dentition and occlusion. It may lead to periodontal complications, abnormal masticatory muscle function, and temporomandibular joint disorders. A number of factors should be taken into account when planning a procedure, such as the condition of a tooth
\end{abstract}

Adres do korespondencji/Correspondence address:

Dorota Jabłonowska

email: dorotajablonowska01@gmail.com

\title{
(1)(2)
}

Copyright: (C) 2005 Polish Orthodontic Society. This is an Open Access journal, all articles are distributed under the terms of the Creative Commons Attribution-NonCommercial-ShareAlike 4.0 International (CC BY-NC-SA 4.0) License (http://creativecommons.org/licenses/by-nc-sa/4.0/), allowing third parties to copy and redistribute the material in any medium or format and to remix, transform, and build upon the material, provided the original work is properly cited and states its license. 
funkcji mięśni żucia i zaburzeń stawów skroniowo-żuchwowych. Planując postępowanie, trzeba wziąć pod uwagę wiele czynników, takich jak stan zęba, którego ekstrakcja jest rozważana, wiek zębowy pacjenta, stopień stłoczeń w odcinku przednim i bocznym, stosunki zwarciowe, obecność i stan pozostałych zębów. Dodatkowo należy rozważyć potrzebę wykonania ekstrakcji balansujących i kompensacyjnych. Wnioski. Wczesna utrata pierwszych stałych trzonowców stanowi duży problem terapeutyczny. U wszystkich pacjentów po wczesnej ekstrakcji pierwszych stałych trzonowców niezbędna jest dokładna ocena kliniczna i radiologiczna. W określonych przypadkach istnieje możliwość samoistnego zamknięcia luki poekstrakcyjnej oraz ograniczenia konieczności przyszłej interwencji ortodontycznej. Aby ustalić postępowanie najkorzystniejsze dla pacjenta, każdy przypadek należy rozpatrywać indywidualnie. (Jabłonowska D, Reszelewska K, Smołka P. Konsekwencje oraz postępowanie w przypadku wczesnej utraty pierwszych stałych trzonowców u dzieci. Forum Ortod 2021; 17 (3): 205-18).

Nadesłano: 18.04.2021

Przyjęto do druku: 31.08.2021

https://doi.org/10.5114/for.2021.110504

Słowa kluczowe: dzieci, wczesna utrata, pierwsze stałe trzonowce, ekstrakcja pierwszych stałych trzonowców

\section{Wstęp}

Wczesna utrata pierwszych stałych zębów trzonowych u dzieci jest poważnym problemem niosącym za sobą liczne konsekwencje oraz stawiającym lekarza prowadzącego przed trudnym dylematem wyboru najwłaściwszego postępowania. Wymaga określenia procedury ograniczającej wystąpienie niepożądanych skutków oraz stwarzającej możliwie najkorzystniejsze warunki dla dalszego prawidłowego rozwoju okluzji. Ekstrakcja pierwszych stałych trzonowców u młodych pacjentów powinna być rozważona w przypadku zębów, których długoterminowe rokowanie jest niepomyślne. Często może okazać się to lepszym rozwiązaniem niż zachowanie zębów, które w dłuższej perspektywie, z dużym prawdopodobieństwem zostaną utracone. Do przyczyn wczesnej utraty pierwszych stałych trzonowców zalicza się próchnicę, hipomineralizację trzonowcowo-siekaczową (MIH), choroby przyzębia, zaburzenia wyrzynania oraz malformację trzonowcowo-siekaczową (MIM) (1). Zdecydowanie największym problemem jest próchnica oraz jej skutki, takie jak destrukcja tkanek twardych zębów, choroby miazgi oraz patologie tkanek okołowierzchołkowych. Badania przeprowadzone w trzech szpitalach dziecięcych w Wielkiej Brytanii wskazują, że to właśnie próchnica jest przyczyną ekstrakcji pierwszych stałych zębów trzonowych w aż 89\% przypadków (2). Istotną przyczyną utraty pierwszych stałych zębów trzonowych u dzieci jest również hipomineralizacja whose extraction is being considered, patient's dental age, degree of crowding in the anterior and lateral segments, occlusal relations, and presence and condition of other teeth. Additionally, the need for balancing and compensating extractions must be considered. Conclusions. Early loss of first permanent molars is a major therapeutic problem. Detailed clinical and radiological evaluation is necessary for all patients. In certain cases, it is possible to achieve spontaneous space closure and reduce the need for future orthodontic intervention. Each case must be evaluated individually to determine the management that is most beneficial to a patient. (Jabłonowska D, Reszelewska K, Smołka $P$. Consequences and management of early loss of first permanent molars in children. Orthod Forum 2021; 17 (3): 205-18).

Received: 18.04 .2021

Accepted: 31.08.2021

https://doi.org/10.5114/for.2021.110504

Key words: children, early loss, first permanent molars, extraction of first permanent molars

\section{Introduction}

Early loss of first permanent molars in children is a severe problem with numerous consequences and poses a difficult dilemma for a clinician in choosing the most appropriate management. It requires defining a procedure to limit the occurrence of undesirable effects and to create the most favorable conditions for continued proper occlusion development. The extraction of first permanent molars in young patients should be considered for teeth with a poor longterm prognosis. It may often be a better solution than retaining teeth that are more likely to be lost in the long term. Causes of early loss of first permanent molars include dental caries, molar-incisor hypomineralization (MIH), periodontal diseases, eruption disorders, and molar-incisor malformation (MIM) (1). The most significant problem is caries and its consequences, such as destruction of dental hard tissues, pulp diseases, and periapical pathologies. Research conducted in three children's hospitals in the United Kingdom indicates that caries is the cause of the extraction of first permanent molars in $89 \%$ of cases (2). Molar-incisor hypomineralization (MIH) is also a significant cause of loss of first permanent molars in children. Recent studies estimate that it affects $13.1 \%$ of the world's population on average (3). A recently discovered disorder, molar-incisor malformation (MIM), is a rare cause of early loss of first permanent molars. Usually, it affects first permanent molars, second deciduous molars and permanent incisors in the maxilla. Molars have normal crowns with an abnormal root structure that is short and narrow. Maxillary permanent incisors may present hypomineralization of the enamel and 
trzonowcowo-siekaczowa (MIH). Najnowsze badania szacują, że występuje średnio u 13,1\% światowej populacji (3). Rzadką przyczyną wczesnej utraty pierwszych stałych zębów trzonowych jest niedawno odkryte zaburzenie, tj. malformacja trzonowcowo-siekaczowa (MIM). Obejmuje ono najczęściej pierwsze stałe zęby trzonowe, drugie mleczne zęby trzonowe oraz stałe zęby sieczne w szczęce. Zęby trzonowe charakteryzuje prawidłowy wygląd koron z zaburzoną budową korzeni, które są krótkie i wąskie. Stałe zęby sieczne szczęki mogą prezentować zmiany hipomineralizacyjne szkliwa oraz bruzdy w przyszyjkowej części korony. U pacjentów z MIM często dochodzi do zatrzymania zębów, ich wczesnej utraty, ze zmniejszeniem ilości miejsca w łuku zębowym. Dużym problemem w tym zaburzeniu są również ropnie przyzębne oraz samoistne bóle zębów $(4,5)$. Wielu autorów próbowało zmierzyć się z problemem wczesnej utraty pierwszych stałych zębów trzonowych u dzieci, ocenić możliwe konsekwencje i stworzyć schemat postępowania optymalizujący dalszy rozwój uzębienia. W niniejszej pracy przedstawiono wyniki badań przeprowadzonych na ten temat.

\section{Cel}

Celem pracy jest omówienie problemu wczesnej utraty pierwszych stałych zębów trzonowych u dzieci. Wzięto pod uwagę takie aspekty jak przyczyny i skutki wczesnej utraty pierwszych stałych trzonowców u dzieci oraz zalecane postępowanie mające na celu zminimalizowanie konieczności leczenia ortodontycznego w przyszłości.

\section{Materiał i metody}

Dokonano przeglądu piśmiennictwa z lat 1970-2020, z wykorzystaniem medycznej bazy danych PubMed, używając słów kluczowych: wczesna utrata, pierwsze stałe trzonowce, ekstrakcja pierwszych stałych trzonowców, dzieci. Spośród uzyskanych wyników wyszukiwania wykorzystano 34 artykuły odpowiadające zagadnieniom poruszanym w niniejszej pracy, uwzględniając jedynie te dotyczące ekstrakcji wykonanych w okresie uzębienia mieszanego i wczesnego stałego.

\section{Wyniki}

\section{Konsekwencje wczesnej utraty pierwszych stałych zębów trzonowych}

Konsekwencje wczesnej utraty pierwszych stałych trzonowców obejmują takie aspekty jak wpływ na przestrzeń poekstrakcyjną, wpływ na rozwój i wyrzynanie drugich i trzecich stałych trzonowców, obecność próchnicy i wypełnień w zębach sąsiadujących z luką poekstrakcyjną, wpływ na siekacze, wpływ na rozwój szkieletowy, wpływ na położenie linii pośrodkowych łuków zębowych, wytworzenie nieprawidłowych nawyków żucia, takich jak żucie jednostronne oraz problemy periodontologiczne $(6,7)$. fissures in the cervical area of the crown. Patients with MIM often suffer from tooth retention and early tooth loss with decreased space in the dental arch. Periodontal abscesses and spontaneous toothache are also significant problems in this disorder $(4,5)$. Many authors have tried to face the problem of early loss of first permanent molars in children to assess possible consequences and create a treatment protocol to optimize further development of the dentition. This paper presents the results of studies conducted on this subject.

\section{Aim}

The aim of this study was to review the problem of early loss of first permanent molars in children. Aspects taken into account included reasons and consequences of early loss of first permanent molars in children, as well as recommended management aimed at minimizing the need for orthodontic treatment in the future.

\section{Material and methods}

The literature from 1970-2020 was reviewed using the available medical database PubMed and the keywords: early loss, first permanent molars, extraction of first permanent molars, children. Of the search results obtained, 34 articles corresponding to the issues discussed in this study were considered, and only those concerning extractions performed during the period of mixed and early permanent dentition were included.

\section{Results}

Consequences of early loss of first permanent molars Consequences of early loss of first permanent molars include aspects such as effects on post-extraction space, effects on the development and eruption of second and third permanent molars, caries and fillings in adjacent teeth, effects on incisors, effects on skeletal development, effects on the position of midlines of dental arches, development of abnormal chewing habits such as unilateral chewing and periodontal diseases $(6,7)$.

\section{Effect on post-extraction space and adjacent teeth}

It was demonstrated that the position of teeth adjacent to the gap after an extracted first permanent molar is influenced by the extraction time. This time is essential when extraction in the mandible is required.

Too early extraction of lower first permanent molars, i.e. before the age of 8 years, may result in a distal drift of a lower second premolar bud. It occurs when the mandibular second premolar is inclined distally beyond the root bifurcation of the second deciduous molar. The absence of the permanent first molar whose mesial root determines a correct 


\section{Wpływ na przestrzeń poekstrakcyjną i zęby sąsiadujące z luką}

Wykazano, że na położenie zębów sąsiadujących z luką po usuniętym pierwszym stałym trzonowcu ma wpływ czas ekstrakcji. Jest on szczególnie ważny w przypadku konieczności ekstrakcji w żuchwie.

Zbyt wczesne ekstrakcje dolnych pierwszych stałych trzonowców, tj. przed 8 r.ż., mogą skutkować dystalnym przemieszczeniem zawiązka dolnego drugiego przedtrzonowca. Dzieje się tak, kiedy drugi przedtrzonowiec żuchwy nachylony jest dystalnie, wykraczając poza bifurkację korzeni drugiego trzonowca mlecznego. Brak obecności pierwszego stałego trzonowca, którego korzeń mezjalny wyznacza prawidłowy kierunek wyrzynania drugiego przedtrzonowca, skutkuje jego wyrznięciem dystalnie, w miejscu po usuniętym trzonowcu. Może również dojść do zaklinowania korony drugiego przedtrzonowca przez koronę drugiego stałego trzonowca lub resorpcji korzeni drugiego stałego trzonowca. Aby temu zapobiec, zaleca się ekstrakcję drugiego mlecznego trzonowca, gdy zawiązek drugiego przedtrzonowca ma w połowie wykształcony korzeń. Umożliwia to swobodne wyrznięcie drugiego przedtrzonowca w odpowiednim dla niego miejscu $(8,9,10)$.

Zbyt późne ekstrakcje dolnych pierwszych stałych trzonowców, tj. wykonane w trakcie lub po wyrznięciu drugich stałych trzonowców, mogą skutkować nachyleniem drugiego stałego trzonowca w kierunku mezjalnym oraz językowym. Siły okluzyjne nasilają tak zapoczątkowane ruchy. Nachylenie językowe zębów postępuje ze względu na cieńszą blaszkę zębodołową od strony językowej niż od policzkowej, co może prowadzić do powstania zgryzu przewieszonego. Ekstrakcja pierwszego stałego dolnego trzonowca może spowodować wydłużenie górnego pierwszego stałego trzonowca. Tak powstała przeszkoda okluzyjna uniemożliwia drugiemu dolnemu trzonowcowi stałemu ruch mezjalny, nasilając jego nachylenie w stronę luki poekstrakcyjnej. Może to predysponować do wystąpienia zaburzeń stawu skroniowo-żuchwowego. Konsekwencją zbyt późnej ekstrakcji jest również niecałkowite zamknięcie przestrzeni poekstrakcyjnej lub niepełny kontakt z drugim przedtrzonowcem, co może prowadzić do zalegania płytki bakteryjnej, a w konsekwencji do rozwoju próchnicy. Może również dojść do dystalnego przemieszczenia drugiego przedtrzonowca (8).

Teli i Aytan na podstawie zdjęć cefalometrycznych dzieci z utraconymi pierwszymi stałymi trzonowcami zauważyli, że przestrzeń poekstrakcyjna zamyka się głównie przez mezjalny ruch drugiego stałego trzonowca (11).

Teo i wsp. zbadali, czy pewne czynniki możliwe do zaobserwowania na zdjęciu pantomograficznym mogą być dobrym predyktorem spontanicznego zamknięcia luki poekstrakcyjnej w przypadku ekstrakcji dolnych pierwszych stałych trzonowców. Do tych czynników należały: obecność zawiązka trzeciego trzonowca dolnego, mezjalne nachylenie drugiego stałego trzonowca dolnego oraz położenie zawiązka direction of the eruption of the second premolar results in its eruption distally, in a position of the removed molar. The crown of the second premolar may also become impacted against the crown of the second permanent molar or the roots of the second permanent molar may become resorbed. In order to prevent this, it is recommended to extract the second permanent molar when the second premolar has a half-developed root. Consequently, it provides the opportunity for the second premolar to erupt in its proper position $(8,9,10)$.

Too late extractions of lower first permanent molars, i.e. extractions performed during or after the eruption of second permanent molars, can result in the inclination of the second permanent molar in a mesial and lingual direction. Occlusal forces intensify the movements thus initiated. The lingual inclination of teeth progresses due to a thinner cortical plate on the lingual side than on the buccal side, and it may lead to the scissors bite. In addition, the extraction of a lower first permanent molar may cause overeruption of the upper first permanent molar. Occlusal obstruction created in this manner disables a mesial movement of the lower second permanent molar, increasing its inclination toward the postextraction space. It may predispose to temporomandibular joint disorders. A consequence of too late extraction also includes incomplete closure of the post-extraction space or incomplete contact with the second premolar, which may lead to the retention of dental plaque and, consequently, the development of caries. Distal displacement of the second premolar may also occur (8).

Based on cephalometric radiographs of children with lost first permanent molars, Teli and Aytan observed that the post-extraction space closed mainly through a mesial movement of the second permanent molar (11).

Teo et al. investigated whether certain factors visible on a pantomographic radiograph could be a good predictor of spontaneous post-extraction space closure in lower first permanent molars extraction cases. These factors included the presence of a lower third molar bud, the mesial inclination of the lower permanent second molar, and the position of the lower second premolar bud in the root bifurcation of the second deciduous molar. The authors found that the presence of all of the above factors on a radiograph resulted in a high success rate $(85 \%)$ in spontaneous space closure after extraction in the mandible (12).

In another study, Teo et al. showed differences in spontaneous space closure after extraction of first permanent molars between the upper and lower arch, with more favorable closure in the upper arch. Additionally, patients with Angle class III showed statistically significant worse postextraction space closure (13).

Jalevik and Moller studied the development of the permanent dentition in a group of 27 children who underwent extractions of one to four first permanent molars due to $\mathrm{MIH}$ between the ages of 5.6 and 12.7 years with the mean of 8.2 
drugiego przedtrzonowca dolnego w okolicy bifurkacji drugiego trzonowca mlecznego. Autorzy wykazali, że obecność na zdjęciu radiologicznym wszystkich powyższych czynników skutkuje dużym odsetkiem powodzeń (85\%) w samoistnym zamknięciu przestrzeni poekstrakcyjnej w żuchwie (12).

Teo i wsp. w innym badaniu wykazali różnice w samoistnym zamknięciu przestrzeni poekstrakcyjnej między łukiem górnym i dolnym, z korzystniejszym zamykaniem się przestrzeni w łuku górnym. Dodatkowo pacjenci z III klasą Angle'a wykazali istotne statystycznie gorsze zamykanie luk poekstrakcyjnych (13).

Jalevik i Moller zbadali rozwój uzębienia stałego w 27-osobowej grupie dzieci, u których wykonano ekstrakcje od jednego do czterech pierwszych stałych trzonowców z powodu MIH w wieku 5,6-12,7 lat ze średnią 8,2. Średni czas obserwacji wynosił 5,7 lat. $W$ około $2 / 3$ badanych przypadków wystąpiło zadowalające samoistne zamknięcie przestrzeni poekstrakcyjnej. Również w około $2 \frac{3}{3}$ przypadków wykazano niewielką mezjoinklinację drugich stałych trzonowców. Nachylenia były częstsze w przypadkach ekstrakcji w żuchwie. Dystalny ruch drugich przedtrzonowców zaobserwowano w mniej niż $1 / 3$ przypadków ekstrakcji w żuchwie. Badanie uwzględniło także ocenę konieczności przyszłego leczenia ortodontycznego spowodowanego konsekwencjami ekstrakcji - wymagało tego 18,5\% dzieci z badanej grupy (14).

Serindere i wsp. ocenili zamknięcie luki poekstrakcyjnej u dzieci, u których ekstrakcja pierwszych stałych trzonowców została wykonana między 8 a 13 rokiem życia. Ocena została przeprowadzona co najmniej 3 lata po ekstrakcji. W prawidłowej pozycji wyrznęło się 44,6\% drugich stałych trzonowców. W 20,5\% przypadków pozostała 1-5 mm przerwa. W 6,02\% przypadków przerwa wynosiła 5-10 mm. Obecność nachylenia korony i/lub rotacji zębów sąsiadujących z luką wystąpiła w 28,9\% przypadków. Ze wszystkich usuniętych pierwszych trzonowców stałych tylko 10,8\% było usuniętych w idealnym momencie, czyli w stadium $\mathrm{E}$ według Demirjiana (15).

Z kolei Rahhal ocenił pozycję, w której wyrznęły się drugie stałe górne trzonowce po ekstrakcji pierwszych stałych górnych trzonowców wykonanej w wieku 10,5 lat. Górne drugie zęby trzonowe stałe wyrznęły się dokładnie dystalnie w stosunku do drugich przedtrzonowców w 84,6\%, w pozostałych $15,4 \%$ przypadków pozostał $1 \mathrm{~mm}$ przestrzeni. Z kolei 23\% drugich stałych zębów trzonowych wyrznęło się w niewielkim zgryzie krzyżowym (16).

\section{Wpływ na rozwój i wyrzynanie drugich i trzecich trzo- nowców stałych \\ Drugie trzonowce \\ Telli i Aytan zaobserwowali w obrazie radiologicznym przyspieszony rozwój oraz wyrzynanie drugich stałych zębów trzonowych po stronie ekstrakcji, w porównaniu ze stroną, po której ekstrakcje nie miały miejsca (11).}

years. The mean follow-up time was 5.7 years. Satisfactory spontaneous post-extraction space closure occurred in about $2 / 3$ of the studied cases. Also, about $2 / 3$ of the cases showed slight mesioinclination of second permanent molars. Inclination was more frequent in the cases of extractions in the mandible. Distal movement of second premolars was observed in less than $1 / 3$ of the extraction cases in the mandible. The study also included an assessment of the need for future orthodontic treatment due to the consequences of extraction, and $18.5 \%$ of children in the studied group required it (14).

Serindere et al. evaluated post-extraction space closure in children in whom the extraction of first permanent molars was performed between 8 and 13 years of age. The evaluation was performed at least three years after extraction. $44.6 \%$ of second permanent molars erupted in the correct position. In $20.5 \%$ of cases, a gap of $1-5 \mathrm{~mm}$ remained. A gap of $5-10 \mathrm{~mm}$ remained in $6.02 \%$ of cases. The presence of crown inclination and/or rotation of the teeth adjacent to the post-extraction gap occurred in $28.9 \%$ of cases. Of all extracted first permanent molars, only $10.8 \%$ were extracted at the ideal time-point i.e. stage E according to Demirjian (15).

On the other hand, Rahhal evaluated the position of upper second permanent molars after the extraction of upper first permanent molars performed at the age of 10.5 years. Upper second permanent molars erupted exactly distally to second premolars in $84.6 \%$ of cases, and in the remaining $15.4 \%$ of cases, $1 \mathrm{~mm}$ of space remained. $23 \%$ of permanent second molars erupted in a slight crossbite (16).

\section{Effects on development and eruption of second and third permanent molars}

\section{Second molars}

In panoramic radiographs, Telli and Aytan observed an accelerated development and eruption of second permanent molars on the extraction side compared to the side where extractions were not performed (11).

\section{Third molars}

Williams and Hosila demonstrated that after the extraction of lower first permanent molars, favorable eruption of lower third molars was achieved in nearly $90 \%$ of the cases, compared to $54 \%$ and $57 \%$ of cases involving the extraction of first and second premolars, respectively (17).

Ay et al. compared the position of retained third molars on pantomographic radiographs in patients after the unilateral loss of a permanent first molar that occurred before the age of 16 years. They used the Pell and Gregory's classification to determine the position of third molars. They showed that the extraction of the first permanent molar allowed more space for the eruption of the third molar, having more influence on its favorable position in relation to the mandibular ramus than the depth of retention (18). 


\section{Trzecie trzonowce}

Williams i Hosila wykazali, że po ekstrakcji dolnych pierwszych stałych trzonowców korzystne wyrznięcie dolnych trzecich zębów trzonowych zostało osiągnięte w niemal 90\% badanych przypadków, w porównaniu do 54\% i 57\% przypadków dotyczących ekstrakcji odpowiednio pierwszych i drugich przedtrzonowców (17).

Ay i wsp. porównali położenie zatrzymanych trzecich zębów trzonowych na zdjęciach pantomograficznych u pacjentów po jednostronnej utracie pierwszego stałego trzonowca, która wystąpiła przed 16. rokiem życia. Do określenia położenia zębów ósmych wykorzystali klasyfikację Pella i Gregory'ego. Wykazali, że ekstrakcja pierwszego stałego trzonowca pozwala uzyskać większą ilość miejsca dla wyrznięcia trzeciego trzonowca, wywierając większy wpływ na jego korzystne położenie w stosunku do gałęzi żuchwy, niż na głębokość zatrzymania (18).

Podobne wyniki otrzymali również Yavuz i wsp., według których wczesna utrata pierwszego stałego trzonowca przyspiesza rozwój zawiązka trzeciego stałego trzonowca i stwarza korzystne warunki dla jego wyrznięcia (19).

\section{Próchnica i wypełnienia w zębach sąsiadujących}

Olivier i wsp. zbadali występowanie próchnicy oraz wypełnień w zębach sąsiadujących z luką poekstrakcyjną po pierwszych stałych trzonowcach. Wyniki wykazują, że znacząco mniej ubytków próchnicowych bądź wypełnień odnotowano na powierzchniach sąsiadujących z luką (powierzchni dystalnej drugiego przedtrzonowca oraz powierzchni mezjalnej drugiego stałego trzonowca) w łuku, w którym wykonano ekstrakcję. Wyjątkiem były drugie stałe zęby trzonowe szczęki. Próchnica bądź wypełnienia powierzchni żujących występowały częściej w drugich stałych zębach trzonowych, niż w drugich zębach przedtrzonowych. Zarówno w drugich stałych zębach przedtrzonowych jak i trzonowych znacząco więcej ubytków lub wypełnień na powierzchniach żujących odnotowano w łuku zębowym, w którym wykonano ekstrakcję pierwszego stałego trzonowca (20).

\section{Wpływ na siekacze}

Richardson przeprowadził analizę porównawczą zdjęć cefalometrycznych wykonanych przed ekstrakcją oraz około roku po ekstrakcji dwóch pierwszych stałych trzonowców żuchwy w grupie dzieci w wieku 8-14 lat w momencie ekstrakcji. Analizy wykazały, że u ponad połowy badanych nagryz pionowy miał tendencję do pogłębiania się, a nagryz poziomy pozostał stabilny. Zwiększenie nagryzu pionowego wydawało się być powiązane ze zwiększeniem retroinkilnacji dolnych siekaczy i proklinacją górnych siekaczy. Pacjenci, którzy wyjściowo mieli wychylone górne i dolne siekacze oraz zwiększony nagryz poziomy wykazywali większą tendencję do pogłębiania nagryzu pionowego po ekstrakcji. Pacjenci bez kontaktu w obrębie zębów przednich przed ekstrakcją, po ekstrakcji zawsze wykazywali zwiększenie
Yavuz et al. also obtained similar results, and according to them, early loss of the first permanent molar accelerates the development of the third permanent molar bud and creates favorable conditions for its eruption (19).

\section{Caries and fillings in adjacent teeth}

Olivier et al. investigated the occurrence of caries and fillings in teeth adjacent to the post-extraction space after first permanent molars. The results show that significantly fewer caries cases or fillings were observed on the surfaces adjacent to the gap (the distal surface of the second premolar and the mesial surface of the second permanent molar) in the arch in which the extraction was performed. Maxillary second permanent molars were the exception. Caries or fillings on occlusal surfaces were more common in second permanent molars than in second premolars. In both second permanent premolars and molars, significantly more cavities or fillings on the chewing surfaces were noted in the arch in which the first permanent molar was extracted (20).

\section{Effects on the incisors}

Richardson conducted a comparative analysis of cephalometric radiographs taken before extraction and approximately one year after extraction of two mandibular first permanent molars in a group of children aged 8-14 years at the time of extraction. These analyses showed that overbite tended to deepen in more than half of the subjects while the overjet remained stable. Increased overbite seemed to be associated with retroinclination of lower incisors and proclination of upper incisors. Patients who initially had protruded upper and lower incisors and increased overjet showed a greater tendency to deepen overbite after extraction. Patients without contact on the anterior teeth before extraction always showed increased overbite after extraction. Overbite did not change after extraction in most patients whose overbite and overjet were normal before extraction. They also noted a tendency to decrease crowding of lower incisors one year after molar extraction (21).

Normando and Cavacami showed that lower incisors retruded in a group of subjects who had both first permanent molars in the mandible removed at a young age. This is proven by an increase in the angle between the long axis of a lower incisor and the NB line. This is also confirmed by a decrease in the IMPA angle (Lower Incisor Mandibular Plane Angle). It is the angle between the long axis of a lower incisor and the GoGn line (Gonion-Gnathion). Furthermore, slight retrusion of lower incisors expressed by a linear measurement of 1:NB (distance of the incisal edge of a lower central incisor from the NB line) was observed. Bilateral extraction of lower first permanent molars did not affect the inclination and anteroposterior position of upper incisors. Results were based on a cephalometric analysis performed at least 5 years after extraction (22). 
nagryzu pionowego. Nagryz pionowy nie zmieniał się po ekstrakcji u większości pacjentów, u których nagryz pionowy i poziomy przed ekstrakcją były prawidłowe. Zauważono również tendencję do zmniejszenia stłoczenia dolnych siekaczy rok po ekstrakcji zębów trzonowych (21).

Normando i Cavacami wykazali, że w badanej grupie osób, które w młodym wieku miały usunięte oba pierwsze trzonowce stałe w żuchwie, dolne siekacze przechyliły się. Dowodem tego jest zwiększenie kąta zawartego między długą osią siekacza dolnego a linią NB. Potwierdza to również zmniejszenie kąta IMPA (Lower Incisor Mandibular Plane Angle). Jest to kąt zawarty między długą osią siekacza dolnego a linią GoGn (Gonion-Gnathion). Ponadto zaobserwowano niewielką retruzję siekaczy dolnych wyrażoną pomiarem liniowym 1 : NB (odległość brzegu siecznego dolnego siekacza przyśrodkowego od linii NB). Obustronna ekstrakcja pierwszych stałych dolnych trzonowców nie wpłynęła na nachylenie i przednio-tylną pozycję górnych siekaczy. Wyniki zostały oparte o analizę cefalometryczną wykonaną co najmniej 5 lat po ekstrakcji (22).

\section{Wpływ na rozwój szkieletowy i symetrię}

Badania przeprowadzone przez Normando i Cavacami opisują również wpływ utraty obu pierwszych stałych trzonowców żuchwy na rozwój szkieletowy. W grupie badanej w stosunku do grupy kontrolnej wykazano zmniejszenie kąta GnSN (Gnathion-Sella-Nasion) określającego przednio-dolny wzrost żuchwy, rotację płaszczyzny zgryzu przeciwną do ruchu wskazówek zegara (anteriorotację) uwidocznioną na podstawie stosunku płaszczyzny zgryzu do podstawy czaszki (kąt OclSN - kąt zawart między linią zgryzową a linią Sella-Nasion) oraz niewielkie zmniejszenie dolnej przedniej wysokości twarzy (LAFH - Lower Anterior Facial Height), jako skutek wymienionych powyżej zmian. Utrata dolnych pierwszych stałych trzonowców nie wpłynęła na relację przednio-tylną szczęki i żuchwy oraz na wydatność bródki (22).

Halicioglu i wsp. zbadali zależność pomiędzy wczesnymi obustronnymi ekstrakcjami pierwszych stałych trzonowców w żuchwie, wykonanymi w wieku do lat 12 , a wystąpieniem asymetrii w obrębie wyrostka kłykciowego i gałęzi żuchwy. Obecność asymetrii w grupach badawczej i kontrolnej, składającej się z przypadków z pełnym uzębieniem, nie ujawniły istotnych statystycznie różnic. Wykazano jednak, że w grupie badawczej wartości długości wyrostka kłykciowego i gałęzi żuchwy były mniejsze niż w grupie kontrolnej (23).

Caglaroglu i wsp. przeprowadzili badania rentgenogramów tylno-przednich czaszki, które podzielili na trzy grupy: pacjentów, u których przeprowadzono ekstrakcję jednego pierwszego trzonowca stałego szczęki przed 12 r.ż.; pacjentów, u których przeprowadzono ekstrakcję jednego pierwszego stałego trzonowca żuchwy przed ukończeniem 12 r.ż.; grupę kontrolną - pacjentów bez ekstrakcji. Badanie miało na celu wykrycie zależności między wykonanymi ekstrakcjami a rozwojem asymetrii szkieletowych twarzowej części czaszki. Zaobserwowano:

\section{Effects on skeletal development and symmetry}

Research conducted by Normando and Cavacami also describes the effects of the loss of both mandibular first permanent molars on skeletal development. The study group compared to the control group showed a decrease in the gnathion-sella-nasion ( $\mathrm{GnSN}$ ) angle defining the anteriorposterior growth of the mandible, counterclockwise rotation of the occlusal plane (anteriorotation) shown by the relation of the occlusal plane to the cranial base (OclSN angle - angle between the occlusal line and Sella-Nasion line), and a slight decrease in the lower anterior facial height (LAFH), as a result of changes mentioned above. The loss of lower first permanent molars did not affect the anteroposterior position of the maxilla and mandible or the prominence of the chin (22).

Halicioglu et al. investigated a relationship between early bilateral extractions of lower first permanent molars performed under the age of 12 years and the occurrence of asymmetry in the condylar process and mandibular ramus. The presence of asymmetry in the study and control groups consisting of cases with complete dentition showed no statistically significant differences. However, it was shown that the values of condylar process and mandibular ramus length were smaller in the study group than in the control group (23).

Caglaroglu et al. conducted a study of cranial posteroanterior roentgenograms, which they divided into three groups: patients who had one maxillary first permanent molar extracted before the age of 12 years; patients who had one mandibular first permanent molar extracted before the age of 12 years; a control group of patients without extractions. This study was designed to detect a relationship between the extractions performed and the development of skeletal asymmetries of the facial part of the cranium. Authors observed:

- $\quad$ an increase in the difference between maxillary and mandibular widths in both extraction groups,

- an increase in the distance between the antegonion point and the midline on the extraction side in both extraction groups,

- a decrease in the distance of the jugular process from the midline on the extraction site in the group of patients with extraction performed in the maxilla,

- an increase in the distance of the jugular process from the midline on the extraction side in the group of patients with extraction performed in the mandible,

- an increase in the distance between the antegonion and menton points on the extraction side in the group of patients with extraction performed in the mandible.

In addition, it was found that the width of the maxilla and mandible in the control group was significantly greater than that in extraction groups. By assessing the midlines of dental arches, they observed a shift toward the extraction side in both extraction groups, but the shift was significantly greater 
- zwiększenie różnicy pomiędzy szerokością szczęki i żuchwy po stronie ekstrakcji w obu grupach ekstrakcyjnych,

- zwiększenie odległości między punktem antegonion a linią pośrodkową po stronie ekstrakcji w obu grupach ekstrakcyjnych,

- zmniejszenie odległości wyrostka szyjnego od linii pośrodkowej po stronie ekstrakcji w grupie pacjentów z wykonaną ekstrakcją w szczęce,

- zwiększenie odległości wyrostka szyjnego od linii pośrodkowej po stronie ekstrakcji w grupie pacjentów z wykonaną ekstrakcją w żuchwie,

- zwiększenie odległości pomiędzy punktami antegonion i menton po stronie ekstrakcji w grupie pacjentów $\mathrm{z}$ wykonaną ekstrakcją w żuchwie.

Ponadto stwierdzono, że szerokość szczęki i żuchwy w grupie kontrolnej była znacząco większa niż w grupach ekstrakcyjnych. Oceniając linie pośrodkowe łuków zębowych, zaobserwowano przesunięcie w stronę ekstrakcyjną w obu grupach ekstrakcyjnych, jednak to przesunięcie było znacząco większe w przypadku ekstrakcji w żuchwie. W grupach ekstrakcyjnych wystąpiło również przesunięcie punktu menton w stronę ekstrakcji (7).

\section{Postępowanie}

Właściwe postępowanie w okresie uzębienia mieszanego oraz wczesnego stałego w stosunku do pierwszych stałych trzonowców, których długoterminowe rokowanie jest niepomyślne, jest kluczowe dla zapewnienia dalszego prawidłowego rozwoju uzębienia, stosunków zwarciowych oraz zminimalizowania potrzeby leczenia ortodontycznego w przyszłości. Odpowiednio zaplanowane ekstrakcje pierwszych stałych trzonowców przy sprzyjających warunkach stwarzają możliwość samoistnego zamknięcia luk poekstrakcyjnych, rozładowania niewielkich stłoczeń oraz zapobiegają rozwinięciu się wady zgryzu. Przed ustaleniem planu leczenia należy wziąć pod uwagę wiele czynników, do których należą:

- stan zęba, którego ekstrakcja jest rozważana,

- wiek zębowy pacjenta,

- stopień stłoczeń w odcinku przednim i bocznym,

- stosunki zwarciowe,

- obecność i stan pozostałych zębów (24).

W przypadkach wymagających ekstrakcji pierwszych stałych trzonowców należy dodatkowo rozważyć konieczność przeprowadzenia ekstrakcji balansujących i kompensacyjnych. Ekstrakcje balansujące to ekstrakcje po przeciwległej stronie tego samego łuku zębowego, które mają na celu zachowanie położenia linii pośrodkowej. Ekstrakcje kompensacyjne to ekstrakcje w łuku przeciwstawnym mające na celu zapobieganie biernemu wyrzynaniu zęba pozbawionego antagonisty. Wydłużanie się górnego pierwszego stałego trzonowca może spowodować zablokowanie mezjalnego przemieszczenia dolnego drugiego trzonowca stałego. Zarówno ekstrakcje balansujące jak i kompensacyjne powinny in the mandibular extraction cases. There was also a shift of the menton point toward the extraction side in the extraction groups (7).

\section{Management}

Appropriate management in the period of mixed and early permanent dentition of first permanent molars with a poor long-term prognosis is essential to ensure further proper development of the dentition and occlusal relationships and minimize the need for orthodontic treatment in the future. Properly planned extractions of first permanent molars under favorable conditions create the possibility of spontaneous closure of post-extraction spaces, unloading of minor crowding and prevent the development of a malocclusion. Before establishing a treatment plan, many factors should be considered, namely:

- condition of a tooth whose extraction is being considered,

- patient's dental age,

- degree of anterior and posterior crowding,

- occlusal relationships,

- presence and condition of other teeth (24).

In cases requiring extraction of first permanent molars, the need for balancing and compensating extractions should be further considered. Balancing extractions are extractions on the opposite side of the same dental arch to preserve the midline position. Compensating extractions are extractions in the opposing arch to prevent overeruption of a tooth lacking an antagonist. Elongation of the upper first permanent molar may block the mesial migration of the lower second permanent molar. Both balancing and compensating extractions should be considered only during the period of mixed dentition, if no future orthodontic treatment is planned. (24)

\section{The condition of a tooth whose extraction is being considered}

Extraction of first permanent molars should be considered when a tooth has extensive occlusal or approximal surface restoration, irreversible pulpitis, periapical inflammation or severe hypoplasia (24).

\section{Patient's dental age}

The stage of development of second permanent molars is of particular importance when deciding to extract first permanent molars. The right time of extraction, i.e. before the eruption of second permanent molars, determines the possibility of spontaneous space closure.

Ekstrand et al. related dental age to the metric age and conducted a study according to which the age of eruption of second permanent molars ranged from 8 years and 11 months to 14 years and 4 months, with the mean of 11.3 years in girls and from 9 years and 11 months to 13 years and 11 months, with the mean of 12 years in boys (25). 
być rozważane jedynie w okresie uzębienia mieszanego, jeśli nie jest planowane przyszłe leczenie ortodontyczne (24).

\section{Stan zęba, którego ekstrakcja jest rozważana}

Ekstrakcja pierwszych stałych trzonowców powinna zostać rozważona, kiedy taki ząb posiada duże odbudowy powierzchni żującej bądź powierzchni stycznych, nieodwracalne zapalenie miazgi, stan zapalny tkanek okołowierzchołkowych bądź znaczny stopień hipoplazji (24).

\section{Wiek zębowy pacjenta}

Szczególne znaczenie w podjęciu decyzji o ekstrakcji pierwszych stałych trzonowców ma stopień rozwoju drugich stałych trzonowców. Odpowiedni czas ekstrakcji, tj. przed wyrznięciem drugich stałych trzonowców, warunkuje możliwość samoistnego zamknięcia luk poekstrakcyjnych.

Odnosząc wiek zębowy do wieku metrykalnego Ekstrand i wsp. przeprowadzili badanie, według którego wiek wyrzynania drugich stałych trzonowców waha się od 8 lat 11 miesięcy do 14 lat i 4 miesięcy, ze średnią 11,3 lat u dziewczynek oraz od 9 lat i 11 miesięcy do 13 lat i 11 miesięcy, ze średnią 12 lat u chłopców (25). Przed 8. rokiem życia w obrazie radiologicznym często nie ma jeszcze widocznych oznak rozwoju trzeciego trzonowca, co dodatkowo komplikuje podjęcie właściwej decyzji terapeutycznej (26). Odpowiedni czas ekstrakcji ma większe znaczenie w przypadku konieczności usunięcia zęba w żuchwie niż w szczęce. Powodem są różne drogi wyrzynania drugich stałych trzonowców szczęki i żuchwy. W szczęce wierzchołek korzenia drugiego stałego trzonowca jest ułożony bardziej mezjalnie w stosunku do jego korony, więc po ekstrakcji pierwszego stałego trzonowca korona zęba podczas wyrzynania nachyli się ku przodowi, ustawiając się prawidłowo w łuku zębowym. W żuchwie wierzchołek korzenia położony jest bardziej dystalnie w stosunku do korony, co skutkuje jeszcze większym nachyleniem mezjalnym zęba podczas wyrzynania (27).

Według Ong i Bleakley szczególnie pomyślne zamknięcie przestrzeni poekstrakcyjnej można osiągnąć wtedy, gdy w momencie ekstrakcji drugi stały ząb trzonowy jest zlokalizowany powyżej połączenia szkliwno-cementowego zakwalifikowanego do ekstrakcji pierwszego stałego trzonowca (28).

Optymalny czas na ekstrakcję pierwszych stałych trzonowców według Thilander i Skagius to 8-10 r.ż., po wyrznięciu siekaczy bocznych, a przed wyrznięciem drugich stałych trzonowców (29).

W odniesieniu do stopnia rozwoju drugich stałych trzonowców zaleca się ekstrakcję pierwszych stałych trzonowców w momencie, kiedy zawiązki drugich stałych trzonowców są wciąż otoczone tkanką kostną, a w obrazie radiologicznym widoczne są punkty mineralizacji w okolicy bifurkacji (stadium E według Demirjiana) $(26,29)$.

Z przeprowadzonego przez Eichenberger i wsp. przeglądu piśmiennictwa na temat optymalnego czasu ekstrakcji źle rokujących pierwszych stałych trzonowców wynika, że dla szczęki jest to wiek 8-10,5 lat, a dla żuchwy 8-11,5 lat (30).
Before the age of 8 years, radiographic evidence of third molar development is often not yet evident, further complicating the appropriate therapeutic decision (26). The appropriate timing of extraction is more important when a tooth must be extracted in the mandible than in the maxilla. The reason is the different paths of the eruption of maxillary and mandibular second permanent molars. In the maxilla, the apex of a root of the second permanent molar is positioned more mesially in relation to its crown. It means that after extraction of the first permanent molar, the tooth crown will lean forward during eruption and position itself properly in the dental arch. In the mandible, the root apex is located more distally to the crown, and it results in even greater mesial inclination of the tooth during the eruption (27).

According to Ong and Bleakley, particularly successful space closure can be achieved when, at the time of extraction, the second permanent molar is located above the cemento-enamel junction of the first permanent molar qualified for extraction (28).

According to Thilander and Skagius, the optimal time for extraction of first permanent molars is 8-10 years of age after the eruption of lateral incisors and before the eruption of second permanent molars (29).

With regard to the stage of development of second permanent molars, it is recommended that first permanent molars be extracted when second permanent molar buds are still within the bone, and the radiographs show points of mineralization in the bifurcation region (Demirjian stage E) $(26,29)$.

A review of the literature by Eichenberger et al. on the optimal time for extraction of poor-prognosis first permanent molars suggests that the age for maxillary extraction is 8-10.5 years and for mandibular extraction 8-11.5 years (30).

Teo et al. conducted studies on the relationship between the stage of development of second permanent molars at the time of extraction of first permanent molars and the degree of post-extraction space closure. Cases in which extractions were performed at stages D to G of second permanent molar development according to Demirjian (D formed crown, E - beginning of bifurcation formation, $F$ - root length equal to or greater than crown height, G - root development almost complete) were included in the study. The study results indicate a certain tendency for more favorable spontaneous space closure in the case of stages $\mathrm{E}$ and F of development compared to stages D and G, but these differences are not statistically significant (13). In another study already cited, Teo et al. show that factors such as the presence of a lower third molar bud, mesial inclination of the lower second permanent molar, and position of the second lower premolar in the bifurcation of the second deciduous molar are significantly better predictors of successful spontaneous space closure than metrical or dental age (12). 
Teo i wsp. przeprowadzili badania nad związkiem pomiędzy stopniem rozwoju drugich stałych trzonowców w momencie ekstrakcji pierwszych stałych trzonowców a stopniem zamknięcia przestrzeni poekstrakcyjnej. Do badania włączono przypadki, w których ekstrakcje zostały wykonane w stadium od D do G rozwoju drugich stałych trzonowców według Demirjiana (D - ukształtowana korona, E - początek formowania bifurkacji, F - długość korzeni równa lub większa wysokości korony, G - rozwój korzenia prawie zakończony). Wyniki badania wskazują na pewną tendencję do korzystniejszego samoistnego zamknięcia przestrzeni poekstrakcyjnej w przypadku stadiów E oraz F rozwoju, w porównaniu do stadiów D i G, różnice te jednak nie są statystycznie istotne (13). W innym, przytaczanym już badaniu, Teo i wsp. wykazują, że czynniki takie jak obecność zawiązka trzeciego trzonowca dolnego, mezjalne nachylenie drugiego stałego trzonowca dolnego oraz położenie drugiego przedtrzonowca dolnego w okolicy bifurkacji drugiego trzonowca mlecznego są znacznie lepszym wyznacznikiem pomyślnego samoistnego zamknięcia luki poekstrakcyjnej niż wiek metrykalny i zębowy (12).

Wu i wsp. przeprowadzili analizę dostępnych badań na temat optymalnego czasu ekstrakcji pierwszych stałych zębów trzonowych. Autorzy stwierdzili, że opierają się one na niehomogennych danych i nie stanowią solidnego dowodu naukowego, zatem nie można na ich podstawie przedstawić jednoznacznych zaleceń na temat optymalnego wieku ekstrakcji. Każdy przypadek należy rozpatrywać indywidualnie, biorąc pod uwagę wiele czynników (31).

\section{Obecność stłoczeń}

Ekstrakcja pierwszego stałego trzonowca może skutkować rozładowaniem obecnego stłoczenia w odcinku bocznym. Nie można natomiast oczekiwać poprawy po ekstrakcji w przypadku znacznych stłoczeń obecnych w odcinku przednim. W takich przypadkach rozsądniej jest utrzymać pierwsze stałe trzonowce w jamie ustnej do momentu wyrznięcia drugich stałych trzonowców. Wówczas uzyskane miejsce może zostać wykorzystane do rozładowania istniejących stłoczeń, wymaga to jednak leczenia ortodontycznego. W przypadku szparowatości powinno unikać się ekstrakcji pierwszych stałych trzonowców na rzecz zastosowania metod odtwórczych (24).

\section{Stosunki zgryzowe}

W podjęciu decyzji o słuszności ekstrakcji źle rokujących pierwszych stałych trzonowców istotne znaczenie mają również warunki zgryzowe.

\section{Klasa I}

W przypadkach I klasy z niewielkimi stłoczeniami zalecana jest ekstrakcja zęba w optymalnym czasie. Nie należy wykonywać ekstrakcji balansujących. Jeśli konieczna jest ekstrakcja dolnego pierwszego trzonowca stałego, można rozważyć
$\mathrm{Wu}$ et al. analyzed available studies on the optimal extraction time for first permanent molars. The authors concluded that they were based on inhomogeneous data and did not provide solid scientific evidence, so no clear recommendations on the optimal extraction age could be made based on them. Instead, each case should be considered individually, taking into account many factors (31).

\section{Presence of crowding}

Extraction of the first permanent molar may result in the unloading of the crowding present in lateral segments. However, no improvement can be expected after extraction if significant crowding is present in the anterior segment. In such cases, it is more reasonable to keep first permanent molars in the mouth until second permanent molars have erupted. Gained space can be used to unload existing crowding, but this requires orthodontic treatment. In cases of spacing in the dental arch, extraction of first permanent molars should be avoided in favor of using restorative methods (24).

\section{Occlusal relationships}

Existing occlusal conditions are also crucial in deciding whether extraction of poor-prognosis first permanent molars is appropriate.

\section{Class I}

In Class I cases with minor crowding, extraction of a tooth at the optimal time is recommended. Balancing extractions should not be performed. If extraction of a lower first permanent molar is necessary, compensating extraction of an opposing tooth may be considered. If extraction of an upper first permanent molar is necessary, compensating extraction of a lower first permanent molar is not recommended, if its condition is good.

In Class I cases with moderate lateral crowding, it is also advisable to extract a tooth at the optimum time to allow second molars to erupt in the correct position and relieve the existing crowding simultaneously. If lateral crowding occurs bilaterally, balancing extractions of the first permanent molar on the opposite side of the dental arch should be considered. Compensating extractions of upper first permanent molars should be considered in maxillary lateral crowding cases. Compensating extractions in the mandible are not recommended.

In the presence of moderate crowding in the anterior segment of the dental arch, only slight improvement can be expected with the extraction of first permanent molars. These extractions can then be delayed until second permanent molars have erupted, and gained space can be used to unload the crowding with fixed appliances. Alternatively, extraction of first permanent molars at the optimum time and postponing treatment of crowding until complete permanent dentition is present can be done $(24,26)$. 
kompensacyjną ekstrakcję zęba przeciwstawnego. Jeśli konieczna jest ekstrakcja górnego pierwszego stałego trzonowca, nie zaleca się wykonywania ekstrakcji kompensacyjnej dolnego pierwszego stałego trzonowca, jeśli jego stan jest dobry.

W przypadkach I klasy z umiarkowanymi stłoczeniami w odcinkach bocznych również zalecana jest ekstrakcja zęba w optymalnym czasie, aby umożliwić wyrznięcie drugich zębów trzonowych w prawidłowej pozycji, z jednoczesnym rozładowaniem istniejących stłoczeń. Jeśli stłoczenia w odcinku bocznym występują obustronnie, należy rozważyć ekstrakcje balansujące pierwszego stałego trzonowca po przeciwnej stronie łuku zębowego. Ekstrakcje kompensacyjne górnych pierwszych trzonowców stałych powinny być rozważone w przypadku stłoczeń w odcinku bocznym szczęki. Nie zaleca się ekstrakcji kompensacyjnych w żuchwie.

W przypadku obecności umiarkowanych stłoczeń w odcinku przednim łuku zębowego można liczyć jedynie na niewielką poprawę dzięki ekstrakcji pierwszych stałych trzonowców. Ekstrakcje można wówczas opóźnić do momentu wyrznięcia drugich stałych trzonowców, a uzyskaną przestrzeń wykorzystać na rozładowanie stłoczeń przy użyciu aparatu stałego. Alternatywą dla tego postępowania jest ekstrakcja pierwszych stałych trzonowców w optymalnym czasie oraz odroczenie leczenia stłoczeń do czasu obecności pełnego uzębienia stałego $(24,26)$.

\section{Klasa II}

W górnym łuku zębowym dodatkowa ilość miejsca po ekstrakcji pierwszych stałych trzonowców może zostać wykorzystana do poprawy relacji zębów siecznych. W przypadku zwiększonego nagryzu poziomego do jego zredukowania o każdy $1 \mathrm{~mm}$ wymagana jest dodatkowa przestrzeń $2 \mathrm{~mm}$ w łuku. Jeśli górne pierwsze stałe trzonowce nie wymagają natychmiastowej ekstrakcji i możliwa jest ich czasowa odbudowa, należy odroczyć ekstrakcję do momentu wyrznięcia drugich trzonowców stałych. Uzyskana przestrzeń może być wykorzystana do korekty wady zgryzu za pomocą aparatów stałych. Aby zapobiec mezjalnej migracji drugiego górnego stałego trzonowca, można wykorzystać łuk podniebienny. Jeśli konieczna jest natychmiastowa ekstrakcja pierwszego stałego trzonowca górnego, można od razu rozpocząć leczenie ortodontyczne aparatem czynnościowym lub aparatem ruchomym połączonym z headgearem w celu poprawy relacji zgryzowych w odcinkach bocznych i jeśli to konieczne, kontynuować później leczenie aparatem stałym. Alternatywnym postępowaniem może być rozpoczęcie leczenia ortodontycznego po wyrznięciu drugich stałych trzonowców. W tej sytuacji należy rozważyć leczenie aparatem dystalizującym lub, jeśli zdjęcia rentgenowskie potwierdzają obecność zawiązków trzecich zębów trzonowych, ekstrakcje dwóch górnych przedtrzonowców w celu korekty ustawienia siekaczy. W dolnym łuku zębowym, jeśli nie ma znaczących stłoczeń, pierwsze stałe trzonowce powinny zostać usunięte w optymalnym czasie, aby umożliwić

\section{Class II}

In the upper dental arch, the additional space after extraction of first permanent molars can be used to improve the relationship of incisors. In the case of increased overjet, additional space of $2 \mathrm{~mm}$ in the arch is required to reduce it by every $1 \mathrm{~mm}$. If upper first permanent molars do not require immediate extraction and temporary restoration is possible, extraction should be postponed until second permanent molars have erupted. The gained space can be used to correct the malocclusion with fixed appliances. A transpalatal arch can be used to prevent mesial migration of the second upper permanent molar. If immediate extraction of the upper first permanent molar is necessary, orthodontic treatment can be started immediately with functional appliances or removable appliances combined with a headgear to improve occlusal relationships in the lateral segments and, if necessary, continue later with fixed appliances. Alternatively, orthodontic treatment may be initiated after the eruption of second permanent molars. In this situation, distalizing appliances should be considered or, if radiographs confirm the presence of third molars, extraction of two upper premolars to correct the position of incisors. Regarding the lower dental arch, if there is no significant crowding, first permanent molars should be removed at the optimal time to allow second permanent molars to erupt properly. In cases of increased overbite, extraction of first permanent molars in the lower arch should be avoided.

Class II cases with severe crowding pose a major therapeutic problem because of the need to regain a significant amount of space to unload crowding and improve overjet. When extraction of the first permanent molar in the lower arch is necessary, extraction can be postponed until the second permanent molar has erupted, and gained space can be used to unload crowding with a fixed appliance. Alternatively, when radiographs confirm the presence of third lower molars, the tooth can be extracted at the optimum time allowing the second permanent molar to erupt in a place of the post-extraction gap and then removing two premolars to correct crowding with fixed appliances. In patients with Class II and crowding, balancing extractions should be considered in both the upper and lower arch in cases where the crowding is symmetrical and shifting the midline of the dental arch should be avoided. In a Class II molar relationship after extraction of lower first permanent molars, the risk of overeruption of upper first permanent molars is low because their mesial surface contacts the distal surface of lower second deciduous molars. Therefore, a compensating extraction of upper first permanent molars is not necessary. However, if such a risk exists, extraction should be considered. The lost space can be regained by subsequent distalization of molars. Compensating extractions of lower molars are not recommended $(24,26)$. 
D. Jabłonowska et al.

prawidłowe wyrznięcie drugich stałych zębów trzonowych. W przypadku zwiększonego nagryzu pionowego należy unikać ekstrakcji pierwszych stałych trzonowców w łuku dolnym.

Przypadki II klasy z dużymi stłoczeniami stwarzają duży problem terapeutyczny ze względu na potrzebę odtworzenia znacznej ilości miejsca w celu rozładowania stłoczeń i poprawy nagryzu poziomego. Kiedy konieczna jest ekstrakcja pierwszego stałego trzonowca w łuku dolnym, można odroczyć ekstrakcję do momentu wyrznięcia drugiego stałego trzonowca i wykorzystać uzyskane miejsce do rozładowania stłoczeń za pomocą aparatu stałego. Alternatywnie, gdy badanie radiologiczne potwierdza obecność trzecich dolnych zębów trzonowych, można usunąć ząb w optymalnym czasie, pozwalając wyrznąć się drugiemu stałemu trzonowcowi w miejscu luki poekstrakcyjnej, a następnie usunąć dwa przedtrzonowce w celu korekcji stłoczeń aparatem stałym. U pacjentów z II klasą oraz stłoczeniami należy rozważyć ekstrakcje balansujące zarówno w łuku górnym jak i dolnym w przypadkach, gdy stłoczenia są symetryczne i chcemy uniknąć przesunięcia linii pośrodkowej łuku zębowego. W relacji trzonowców w klasie II po ekstrakcji dolnych pierwszych stałych trzonowców ryzyko biernego wyrzynania górnych pierwszych stałych trzonowców jest niewielkie, ponieważ ich powierzchnia mezjalna kontaktuje się z powierzchnią dystalną dolnych drugich trzonowców mlecznych. Nie jest zatem konieczna ekstrakcja kompensacyjna górnych pierwszych stałych trzonowców. Jeśli natomiast takie ryzyko istnieje, wówczas ekstrakcja powinna zostać rozważona. Utracone miejsce może zostać odzyskane przez późniejszą dystalizację trzonowców. Ekstrakcje kompensacyjne dolnych trzonowców nie są zalecane $(24,26)$.

\section{Klasa III}

W przypadkach III klasy nie należy wykonywać ekstrakcji balansujących i kompensacyjnych. Źle podjęta decyzja dotycząca ekstrakcji pierwszych stałych trzonowców może utrudniać osiągnięcie zadowalających wyników przyszłego leczenia ortodontycznego, skutkując nieprawidłowym nagryzem poziomym w przypadkach leczenia kamuflażowego wad klasy III. Z kolei w przypadkach wymagających zabiegu ortognatycznego ekstrakcje dolnych pierwszych stałych trzonowców mogą uniemożliwiać prawidłową dekompensację wady $(28,29)$.

\section{Obecność i stan pozostałych zębów}

Przed podjęciem decyzji o ekstrakcji pierwszych stałych trzonowców wymagane jest dokładne badanie kliniczne i radiologiczne w celu oceny obecności i stanu pozostałych zębów. W przypadku konieczności wykonania ekstrakcji balansujących po przeciwległej stronie łuku, należy wybrać ząb o najgorszym rokowaniu długoterminowym. Brak zawiązków trzecich stałych zębów trzonowych nie jest bezwzględnym przeciwwskazaniem do ekstrakcji pierwszych

\section{Class III}

Balancing and compensating extractions should not be performed in Class III cases. A poor decision regarding the extraction of first permanent molars may hinder satisfactory results of future orthodontic treatment causing incorrect overjet in cases of camouflage treatment of Class III malocclusions. Conversely, in cases requiring orthognathic surgery, extractions of lower first permanent molars may indispose proper decompensation of the malocclusion $(28,29)$.

\section{Presence and condition of remaining teeth}

Before deciding to extract first permanent molars, a thorough clinical and radiographic examination is required to evaluate the presence and condition of the remaining teeth. If balancing extractions on the opposite side of the arch are necessary, the tooth with the worst long-term prognosis should be selected. The absence of third permanent molar buds is not an absolute contraindication to the extraction of first permanent molars, but the forces released by mesially directed development of third molars may help close the post-extraction space (24). Agenesis of third molars can be challenging to ascertain, as their development may remain invisible on radiographic imaging until the age of 12 years or even later (32). However, a study of a population of Czech children has shown that agenesis of third molars can be confirmed if they are missing by the age of 13 years (33).

In cases where it is recommended to postpone extraction of first permanent molars, it is not necessary to perform complete endodontic treatment of these teeth with the restoration of lost hard tissues. A reasonable solution is to use ART (Atraumatic Restorative Treatment) with temporary glass ionomer restorations, which does not expose the patient to additional unnecessary costs (34).

\section{Conclusions}

Early loss of first permanent molars in children has many consequences for the developing occlusion. There is no doubt that it represents a major therapeutic problem. No unequivocal guidelines for the management of these patients have been presented so far. Many authors have attempted to determine the most advantageous time for extraction of first permanent molars, but studies are based on inhomogeneous data, and their results are inconclusive. A thorough clinical and radiographic evaluation is essential in all patients requiring early extraction of first permanent molars. In certain cases, it is possible to achieve spontaneous space closure and reduce the need for future orthodontic intervention. Factors favoring spontaneous space closure and limiting the need for orthodontic treatment include extraction before the eruption of the second permanent molar and after the eruption of permanent incisors; presence of the third molar bud; maxillary extraction, and absence of dental and 
stałych trzonowców, jednak siły wyzwalane przez mezjalnie ukierunkowany rozwój trzecich trzonowców mogą pomóc w zamykaniu przestrzeni poekstrakcyjnej (24). Agenezja zębów ósmych może być trudna do stwierdzenia, gdyż w obrazie radiologicznym ich rozwój może pozostać niewidoczny do 12 r.ż. lub jeszcze później (32). Badania przeprowadzone na populacji dzieci czeskich wykazały, że agenezję zębów ósmych można stwierdzić w przypadku ich braku do 13. roku życia (33).

W przypadkach, w których zaleca się odroczenie ekstrakcji pierwszych stałych trzonowców, nie ma konieczności przeprowadzania pełnego leczenia endodontycznego tych zębów z odbudową utraconych tkanek twardych. Słusznym rozwiązaniem jest zastosowanie techniki ART (Atraumatic Restorative Treatment) z tymczasową odbudową glassjonomerową, co nie naraża pacjenta na dodatkowe niepotrzebne koszty (34).

\section{Wnioski}

Wczesna utrata pierwszych stałych trzonowców u dzieci niesie za sobą wiele konsekwencji dla rozwijającej się okluzji. Nie ulega wątpliwości, że stanowi duży problem terapeutyczny. Nie przedstawiono dotychczas jednoznacznych wytycznych dotyczących postępowania u tych pacjentów. Wielu autorów podejmowało próbę określenia najkorzystniejszego czasu ekstrakcji pierwszych stałych trzonowców, jednak badania zostały oparte na niehomogennych danych, a ich wyniki są niejednoznaczne. U wszystkich pacjentów wymagających wczesnej ekstrakcji pierwszych stałych trzonowców niezbędna jest dokładna ocena kliniczna i radiologiczna. W określonych przypadkach istnieje możliwość samoistnego zamknięcia luki poekstrakcyjnej oraz ograniczenia konieczności przyszłej interwencji ortodontycznej. Do czynników sprzyjających samoistnemu zamknięciu luki i ograniczeniu konieczności leczenia ortodontycznego należą: ekstrakcja przed wyrznięciem drugiego stałego zęba trzonowego, a po wyrznięciu stałych siekaczy; obecność zawiązka trzeciego zęba trzonowego; ekstrakcja w szczęce oraz brak zaburzeń zębowych i szkieletowych. W przypadku konieczności ekstrakcji pierwszego stałego trzonowca w żuchwie opisywana jest triada czynników (tj. mezjalne nachylenie drugiego stałego trzonowca, obecność zawiązka trzeciego zęba trzonowego oraz położenie zawiązka drugiego przedtrzonowca w bifurkacji drugiego mlecznego trzonowca), które, gdy występują jednocześnie, sprzyjają samoistnemu zamknięciu luki poekstrakcyjnej. Aby ustalić postępowanie najkorzystniejsze dla pacjenta, każdy przypadek należy rozpatrywać indywidualnie. skeletal disorders. When a mandibular first permanent molar must be extracted, a triad of factors are described (i.e., mesial inclination of the second permanent molar, presence of a third molar bud, and position of the second premolar bud in the bifurcation of the second deciduous molar) that, when present simultaneously, promote spontaneous space closure. Each case should be considered individually, taking many factors into account, to determine the most favorable treatment for the patient. 


\section{Piśmiennictwo / References}

1. Mathu-Muju KR, Kennedy DB. Loss of Permanent First Molars in the Mixed Dentition: Circumstances Resulting in Extraction and Requiring Orthodontic Management. Pediatr Dent 2016; 38: 46-53.

2. Albadri S, Zaitoun H, McDonnell ST, Davidson LE. Extraction of first permanent molar teeth: results from three dental hospitals. Br Dent J 2007; 203: E14.

3. Schwendicke F, Elhennawy K, Reda S, Bekes K, Manton DJ, Krois J. Global burden of molar incisor hypomineralization. J Dent 2018; 68: $10-8$.

4. Vargo RJ, Reddy R, Da Costa WB, Mugayar LRF, Islam MN, Potluri A. Molar-Incisor Malformation: Eight New Cases and a Review of the Literature. Int J Paediatr Dent 2020; 30: 216-24.

5. Lee HS, Kim SH, Kim SO, Lee JH, Choi HJ, Jung HS, Song JS. A new type of dental anomaly: molar-incisor malformation (MIM). Oral Surg Oral Med Oral Pathol Oral Radiol 2014; 118: 101-9.

6. Saber AM, Altoukhi DH, Horaib MF, El-Housseiny AA, Alamoudi NM, Sabbagh HJ. Consequences of early extraction of compromised first permanent molar: a systematic review. BMC Oral Health 2018; 18: 59.

7. Cağlaroğlu M, Kilic N, Erdem A. Effects of early unilateral first molar extraction on skeletal asymmetry. Am J Orthod Dentofacial Orthop 2008; $134: 270-5$.

8. Williams JK, Gowans AJ. Hypomineralised first permanent molars and the orthodontist. Eur J Paediatr Dent 2003; 4: 129-32.

9. Spyropoulos ND. Orientation and eruptive patterns of the mandibular second premolar. Oral Surg Oral Med, Oral Pathol 1990; 69: 642-6.

10. Conway M, Petrucci D. Three cases of first permanent molars extractions where extraction of adjacent second deciduous molar is also indicated. Dent Update 2005; 32: 338-42.

11. Telli AE, Aytan S. Changes in the dental arch due to obligatory early extraction of first permanent molars. Turk Ortodonti Derg 1989; 2: $138-43$

12. Teo TKY, Ashley PF, Derrick D. Lower first permanent molars: developing better predictors of spontaneous space closure. Eur J Orthod 2016; 38: 90-5.

13. Teo TKY, Ashley PF, Parekh S, Noar J. The evaluation of spontaneous space closure after the extraction of first permanent molars. Eur Arch Paediatr Dent 2013; 14: 207-12.

14. Jälevik B, Möller M. Evaluation of spontaneous space closure and development of permanent dentition after extraction of hypomineralized permanent first molars. Int J Paediatr Dent 2007; 17: 328-35.

15. Serindere G, Bolgul B, Parlar T, Cosgun A. Effects of first permanent molar extraction on space changes observed in the dental arch using data mining method. Niger J Clin Pract 2019; 22: 936-42.

16. Rahhal AA. Extraction timing of heavily destructed upper first permanent molars. Open J Stomatol 2014; 4: 161-8.

17. Williams R, Hosila FJ. The effect of different extraction sites upon incisor retraction. Am J Orthod 1976; 69: 388-410.
18. Ay S, Agar U, Biçakçi AA, Köşger HH. Changes in mandibular third molar angle and position after unilateral mandibular first molar extraction. Am J Orthod Dentofacial Orthop 2006; 129: 36-41.

19. Yavuz I, Baydaş B, Ikbal A, Dağsuyu IM, Ceylan I. Effects of early loss of permanent first molars on the development of third molars. Am J Orthod Dentofacial Orthop 2006; 130: 634-8.

20. Oliver SJ, Dummer PM, Oliver RG, Hicks R, Addy M, Kingdon A, Shaw WC. The relationship between loss of first permanent molar teeth and the prevalence of caries and restorations in adjacent teeth: a study of 15-16-year-old children. J Dent 1988; 16: 155-9.

21. Richardson A. Spontaneous Changes in the incisor relationship following extraction of lower first permanent molars. Br J Orthod 1979; 6: 85-90

22. Normando D, Cavacami C. The influence of bilateral lower first permanent molar loss on dentofacial morphology - a cephalometric study. Dent Press J Orthod 2010; 15: 100-6.

23. Halicioglu K, Celikoglu M, Caglaroglu M, Buyuk SK, Akkas I, Sekerci AE. Effects of early bilateral mandibular first molar extraction on condylar and ramal vertical asymmetry. Clin Oral Investig 2013; 17: $1557-61$

24. Gill DS, Lee RT, Tredwin CJ. Treatment planning for the loss of first permanent molars. Dent Update 2001; 28: 304-8.

25. Ekstrand KR, Christiansen J, Christiansen MEC. Time and duration of eruption of first and second permanent molars: a longitudinal investigation. Community Dent Oral Epidemiol 2003; 31: 344-50.

26. Cobourne MT, Williams A, Harrison M. National clinical guidelines for the extraction of first permanent molars in children. Br Dent J 2014; 217: 643-8.

27. Crabb JJ, Rock WP. Treatment planning in relation to the first permanent molar. Br Dent J 1971; 131: 396-401.

28. Ong DCV, Bleakley JE. Compromised first permanent molars: an orthodontic perspective. Aust Dent J 2010; 55: 2-14.

29. Thilander B, Skagius S. Orthodontic sequelae of extraction of permanent first molars. A longitudinal study. Rep Congr Eur Orthod Soc 1970; 429-42.

30. Eichenberger M, Erb J, Zwahlen M, Schätzle M. The timing of extraction of non-restorable first permanent molars: a systematic review. Eur J Paediatr Dent 2015; 16: 272-8.

31. Wu M, Chen L, Bawole E, Anthonappa RP, King NM. Is there sufficient evidence to support an optimum time for the extraction of first permanent molars? Eur Arch Paediatr Dent 2017; 18: 155-61.

32. Zandi M, Shokri A, Malekzadeh H, Amini P, Shafiey P. Evaluation of third molar development and its relation to chronological age: a panoramic radiographic study. Oral Maxillofac Surg 2015; 19: 183-9.

33. Rozkovcová E, Dostalova T, Markova M, Broukal Z. The third molar as an age marker in adolescents: new approach to age evaluation. J Forensic Sci 2012; 57: 1323-8.

34. Elsheikh M, Ali A. Planned extraction of first permanent molars during late childhood: A clinical note and mini-review. Dent Oral Craniofac Res 2015; 1: 77-80. 